\title{
Perceived external prestige as a mediator between quality of work life and organisational commitment of public sector employees in Ghana
}

\author{
Authors: \\ Oluyinka Ojedokun ${ }^{1,2}$ \\ Erhabor S. Idemudia ${ }^{1}$ \\ Mercy Desouza ${ }^{3}$ \\ Affiliations: \\ ${ }^{1}$ Department of Psychology, \\ North-West University, \\ Mafikeng Campus, \\ South Africa \\ ${ }^{2}$ Department of Pure and \\ Applied Psychology, Adekunle \\ Ajasin University, Nigeria \\ ${ }^{3}$ Department of Psychology, \\ University of Ghana, Ghana \\ Correspondence to: \\ Oluyinka Ojedokun \\ Email: \\ yinkaoje2004@yahoo.com \\ Postal address: \\ Private Bag X2046, \\ Mmabatho 2735, South \\ Africa \\ Dates: \\ Received: 22 April 2014 \\ Accepted: 27 Jan. 2015 \\ Published: 07 Apr. 2015 \\ How to cite this article: \\ Ojedokun, O., Idemudia, \\ E.S., \& Desouza, M. (2015). \\ Perceived external prestige \\ as a mediator between \\ quality of work life and \\ organisational commitment \\ of public sector employees \\ in Ghana. SA Journal of \\ Industrial Psychology/ \\ SA Tydskrif vir \\ Bedryfsielkunde, 41(1), Art. \\ \#1216, 10 pages. http:// \\ dx.doi.org/10.4102/sajip. \\ v41i1.1216
}

Scan this QR
code with your
smart phone or
mobile device
to read online.

Orientation: Research efforts have been directed at understanding the relationship between quality of work life and organisational commitment, but these studies have not elucidated the mediating role of perceived external prestige in this relationship.

Research purpose: This research seeks to close a research gap by determining the role of perceived external prestige in the relationship between quality of work life and organisational commitment amongst public sector employees in Ghana.

Research approach, design and method: Theoretically guided hypotheses and models were formulated and tested with hierarchical multiple regression statistics using data from a sample of 137 employees from two public sector organisations in Ghana.

Main findings: The results support the hypothesis that quality of work life is positively related to both perceived external prestige and organisational commitment. Also, perceived external prestige was found to predict organisational commitment and partially mediate the relationship between quality of work life and organisational commitment.

Practical/managerial implications: The findings imply that one sure way to enhance organisational commitment of employees is by improving their quality of work life and boosting their perceptions of external prestige of the organisation. These results will be of particular interest to policymakers, public organisations and stakeholders interested in increasing organisational commitment of their employees.

Contribution/value-add: The findings extend previous research by establishing the mediating role of perceived external prestige in the relationship between quality of work life and organisational commitment. If managers of organisations wish to improve organisational commitment, it is wise to institutionalise an organisational culture that promotes good quality of work life and boost the external prestige of the organisation in the employees' mind.

\section{Introduction}

Organisational commitment (OC) has generally been an area of interest to scholars and practitioners in public and private organisations because employees who display high levels of commitment primarily pursue organisational goals, whereas those with low commitment concentrate on achieving their personal goals (Bagtasos, 2011). In other words, harnessing commitment is central to enhancing performance of employees. It is not surprising that academics, practitioners and supervisors in organisations are not underestimating the commitment of employees.

Indeed, researchers have established relationships between OC and both contextual factors and personal characteristics. Contextual factors examined include compensation, career opportunity, training and development, supervisor support, job autonomy, work life policies, skill varieties, trust, new public management belief and cultural positivity (Ahsan, Fie, Foong \& Alam, 2013; Damayanty, 2009; Hausmann, Mueller, Hattrup \& Spiess, 2013; Williamsa, Raynerb \& Allinson, 2012). Researchers have also enumerated the personal characteristics affecting OC to include the five-factor model, positive affectivity-negative affectivity, selling skills and degree of job liking (Goldberg, 1990; Moss, McFarland, Ngu \& Kijowska, 2007; Simintiras, Watkins, Ifie \& Georgakas, 2012).

Apart from the mentioned antecedents, workers have also identified challenging work environments, organisational support, work life balance and work experience as important 
to their OC (Efraty \& Sirgy, 2004; Meyer \& Allen, 1997). Consequently, organisations are focusing on employee work experience such as quality of work life (QWL) because of the assumption that happy employees tend to be more committed (May, Lau \& Johnson, 1999).

Although a great deal has been learned about the relationship between QWL and OC in Western nations, there is a dearth of studies regarding the QWL-OC link amongst public sector employees in Ghana. It is also worthy to note that most existing research on QWL-OC link from South Africa, Thailand and India (e.g. Geldenhuys, Łaba \& Venter, 2014; Koonmee, Singhapakdi, Virakul \& Lee, 2011; Ma, Ma, Yu \& Hao, 2011; Raja \& Kumar, 2013) used employees from corporate companies, hotel businesses, steel companies and human resources. These samples limit generalisation of the results to public sector employees. Nevertheless, research evidence suggests that QWL can influence behavioural responses such as job involvement and OC (Lee, Singhapakdi \& Sirgy, 2007).

\section{The Ghana context}

In Ghana, managers in public organisations have identified low commitment as a problem amongst their employees (Antwi, 2009; Asiedu, 2010). In-depth opinion polls conducted amongst different stakeholders by researchers also revealed that lateness and leaving the workplace during official hours without permission in pursuance of private businesses are becoming acceptable traditions amongst public sector employees. In addition, many qualified public workers look for the slightest opportunity to migrate to the private sector or out of the country to seek better job prospects.

The above-mentioned attitudes exemplify lack of commitment, which may impact negatively on performance of public organisations and can breed a culture of personalissimo, defined by Triandis (1984) as the social process of knowing somebody who knows somebody who knows someone from whom you need a service. Some public servants are also reluctant to render service promptly without bribery, or 'palm rubbing' as it is known in Ghana, or if the client is not personally known to them or related to someone who knows them (Tankebe, 2010). Therefore, knowledge of factors that can help in boosting OC is considered important in improving the understanding of employees' behaviours and making appropriate policies aimed at enhancing the performance of public organisations as a consequence.

According to Mowday, Porter and Steers (1982), OC is the relative strength of an individual's identification and involvement in a particular organisation, characterised by a strong belief in the organisation's goals and acceptance of its values, a willingness to exert maximum effort in the interest of the organisation and a strong desire to maintain membership of the organisation. Employee commitment has implications for organisational outcomes, such as turnover intention, absenteeism, counter-productive behaviour, job satisfaction, motivation and organisational citizenship behaviours.
The useful lens for examining the QWL-OC is the social exchange theory (Blau, 1964), which suggests that due to a balance in exchange relationship, employees who experience high QWL should be more committed. That is to say that OC may decline if there is an imbalance in their perception of input and QWL. However, Homans (1961) argues that the processes of exchange are more complex than allowed for within the conceptual confines of the dyad. A possible explanation may be that the process of rewarding an individual for an activity can be roundabout rather than direct. He further explains that the social exchange relationship is not linear but may involve other independent interactions, depending on the context. Thus, to fully understand the bases and extent of the interaction between employee perceptions and work outcomes, researchers should not limit their investigations to the direct relationships but also should focus on other indirect social transactions that can influence these direct relationships. Fuller, Hester, Barnett, Frey and Relyea (2006) agree that the indirect social transactions may supplement or even replace the direct social transactions in certain situations.

Blau (1964) and Thibaut and Kelley (1959) reiterate that without considering the roles of intervening variables in social exchange theory (SET), researchers may not be providing a complete explanation of linkages between variables studied, which leads to a constricted view of SET. Unfortunately, very little effort has been made to ascertain the tenacity of this idea, although researchers (e.g. Guerrero \& Herrbach, 2009; Smidts, Pruyn \& Van Riel, 2001) have suggested that identity-related constructs such as perceived external prestige (PEP) can be used in moderating the relationship between job satisfaction, productivity, reward systems, physical work environment, rights and OC. One limitation of these studies is that they have not elucidated the mediating role of PEP in the QWL-OC link.

PEP is akin to the concept of la conscience professionelle (Monroe, 1983), defined as the process of deriving selfesteem from identifying with one's organisation or job. Munene (1995) provides evidence that African employees' OC could be enhanced if their cultural characteristic of the need for prestige is encouraged. Young, Worchel and Woehr (1998) suggest that identity management strategies may be effective in achieving organisational outcomes as well as the traditional incentive-based approaches. The mediating role of PEP in the QWL-OC link is worthy of further enquiry with the understanding that offering extrinsic incentives has not achieved the desired results amongst public organisation employees in Ghana (Tankebe, 2010). Thus, there is a need for studies that examine the concept that might strengthen the relationship between QWL and OC.

Therefore, in the present study, using SET (Blau, 1964), the social identity theory (Tajfel, 1978) and self-consistency theory (Korman, 1977) as theoretical frameworks, we examined the mediating role of PEP in the QWL-OC link in a sample of public sector employees in Ghana. Prior to this study, only Huang, Lawler and Lei (2007) have examined the moderating effect of gender, age and educational level on the QWL-OC relationship in Taiwan. In view of the identified 
problems, this study was designed to fill a gap in knowledge by addressing the following questions:

- To what extent are QWL and OC related?

- To what extent are QWL and PEP related?

- Would PEP mediate the relationship between QWL and OC?

\section{Aim of the study}

The main objective of the current study was to determine whether QWL is significantly related to PEP and, consequently, to OC amongst public sector employees in Ghana. More specifically, the sub-objectives of the study were to investigate:

- Whether QWL is significantly related to OC.

- Whether QWL is significantly related to PEP.

- Whether PEP acts as a mediator between QWL and OC.

The findings will contribute to both theory and practice, the latter being very important at this time when researchers are being urged to apply academic theories to practice and move towards applying research findings to solve social and organisational problems. From the practical perspective, the article addresses an existing gap in the literature on the potential mediating role of PEP on the QWL-OC link. If PEP does mediate the QWL-OC link, then this has implications for human resource managers and decision-makers, with direct relevance to issues such as employees' well-being, training, assessment and perceptions, amongst others. For theory, this article will highlight the importance of integrating SET, SIT and self-consistency theory to explain employees' actions, perceptions and attitudes.

In the subsequent parts of this article, the theoretical framework and hypotheses to be tested will be outlined and the research approach, participants, instruments, procedure and data analysis are discussed. Finally, the results and findings are discussed with regard to the managerial implications for public organisation managers. Some conclusions and suggestions for further research are offered as well.

\section{Theoretical framework, review of the literature and hypotheses}

Social exchange theory suggests that satisfaction with an exchange relationship motivates employees to exhibit positive outcomes (Bagtasos, 2011). From a social identity theory viewpoint, individuals prefer membership of groups that are evaluated more positively in comparison with other potential social categories (Haslam, 2004). Thus, membership of a highly rated organisation enhances employees' personal identity and contributes positively to their self-concept. In order to maintain self-consistency, employees will continue to identify with the organisational interest and exhibit behaviours that will aid the organisation in achieving its goals (Korman, 1977).

\section{QWL, OC and PEP in SET and SIT}

Reasoning in line with SET (Blau, 1964) and norm of reciprocity (Gouldner, 1960), employment relationship is an exchange relationship within which responsibilities are fulfilled in expectations that particular rewards will be received. Theoretically, favourable exchanges will increase employees' propensity to reciprocate benefits received from the organisation (based on equitable balance of contributions and benefits) with positive work outcomes. From a social exchange perspective, the perception of QWL can have an impact on the OC of employees.

Quality of work life is a multifaceted concept that emphasises provision of a good work life balance for the employees with the goal of qualitatively boosting the total work climate of any organisation (Rathi, 2010). Lee et al. (2007) define QWL as a set of work activities and resources that enables workers to satisfy personal needs and gives them a general feeling of well-being. The key elements of QWL in the literature include job security, job satisfaction, better reward system, employee benefits, professional development, employee involvement and work life balance (Havlovic, 1991; Vagharseyyedin, Vanaki \& Mohammadi, 2011). For the purpose of this article, QWL is an indicator of the overall quality of the human experience in the workplace. The extent to which an organisation can satisfy the personal needs of employees will determine whether employees evaluate their whole experiences of QWL as positive or negative.

Generally, the more employees believe that the organisation caters for their QWL, the more they feel obligated to reciprocate the good gesture with better work outcomes like OC (Ma et al., 2011; Normala, 2010). The argument that employees will reciprocate if they value the outcomes of the exchange relationship has been supported by Meyer and Allen (1996). They conclude that employees who perceive high QWL will develop higher commitment to the organisation compared to those who grade their QWL poorly. This should be expected because social values and norms (e.g. the norm of reciprocity) inform human behaviour and compel people to feel obliged to reciprocate the benefits received through the relationship (Fuller et al. 2006).

Researchers who have investigated the effects of QWL on OC using SET (Bagtasos, 2011; Saklani, 2010) and the norm of reciprocity (Rhoades \& Eisenberger, 2002) have identified perceived QWL as an organisational factor that influences employee behaviours. They found that when employees felt that they were being adequately compensated in relation to their work inputs, it enhanced their perception of quality of work life, which in turn resulted in their willingness to exhibit commitment behaviours. Farh, Podsakoff and Organ (1990) argued that the extent to which jobs allow employees to use and develop their skills and competencies have implications for the appraisal of QWL. They explain further that when the job is structured to give meaning and fulfilment to the employees, it may influence behaviours like commitment. Thus it is hypothesised that QWL will have a positive and significant impact on OC.

According to Sung \& Yang (2008), PEP concerns individuals' interpretations and assessments of companies' prestige, 
based on their own exposure to information about the organisations. It should be noted that PEP is not the same as organisational image or organisational reputation. PEP is a socio-emotional resource that employees derive from interpreting the feedback gained from interactions with organisational outsiders. Organisational image or reputation, on the other hand, is the image that outsiders and stakeholders have formed and hold about an organisation (Fuller et al. 2006). Thus, PEP is dependent on employees' interpretation of information on how outsiders positively or negatively evaluate the organisation in terms of its attributes and actions.

Social identity theory posits that people tend to internalise their experience at work. If that is so, then the perception of QWL can exert an influence on their self-image. When individuals perceive high QWL, their PEP may be increased because favourable perception of their whole work experience can serve as a means of establishing and communicating social status as members of a good organisation and this, in turn, impacts self-esteem. Following this logic, QWL will influence PEP.

Viewed from the social exchange perspective, PEP is a status-related evaluation that can influences employees' OC. The more positively employees think that the status and prestige of their organisation is viewed by the outside world, the more positive they feel about themselves because of their association with this prestigious organisation, which helps in building their positive social identity. As a result, their commitment to the organisation is strengthened. Furthermore, and in line with social identity theory, if organisational members see their organisation as more respected or viewed as more prestigious by important outsiders, OC is more likely to be present, because it could boost someone's self-image (Dutton, Dukerich \& Harquail, 1994). Based on the assumptions of SIT, it is expected that the identity-related benefits of PEP will motivate employees to react positively to the organisation since they consider themselves as members of an in-group that is admired.

Researchers have used SIT to examine the relationship between PEP and employee attitudes. Carmeli (2005) explains that when employees are of the opinion that their organisation is perceived in a positive light by outsiders, they may bask in its reflected glory. Ashforth and Mael (2002) found that PEP indirectly gives employees an attractive social standing that satisfies their self-esteem needs. Smidts et al. (2001) are of the view that since PEP connotes identification with the organisation's positive attributes, it is likely to influence OC. Herrbach, Mignonac and Gatignon (2004) support the idea that PEP has a positive impact not only on employee commitment, but also on other pleasant affective states in the workplace. According to Bhattacharya and Elsbach (2002), when employees perceive the external prestige of their organisation negatively, they may dis-identify with the organisation and engage in actions that are not beneficial to the organisation. PEP initiates a comparison between the self-esteem derivable from the present organisation to those of a 'comparison other' or 'referent' (Tyler \& Blader, 2003). When employees perceive that they experience higher selfesteem from the present organisation compared to those of a 'comparison other' or 'referent', they will be motivated to increase their levels of $\mathrm{OC}$ to derive more self-esteem from the organisation. PEP can thus be expected to influence OC.

\section{PEP as a mediator of the QWL-OC relationship in self-consistency theory}

A variable may be called a mediator to the extent that it accounts for the relation between the predictor and the criterion (Baron \& Kenny, 1986). In other words, mediation takes place when an independent variable exerts its influence on the dependent variable primarily through a mediator.

Enlightened by the evidence that identity-related constructs are important in the development of OC (Guerrero \& Herrbach, 2009), we conceptualised the mediating role of PEP in the QWL-OC relationship through self-consistency theory. A guiding assumption is that QWL influences OC directly as well as indirectly via the intervening variable of PEP. Within this conceptualisation, to maintain consistency, favourable perception of QWL should motivate a positive rating of $\mathrm{PEP}$, and positive rating of PEP in turn stimulates more OC. Therefore, PEP should mediate the QWL-OC link because the favourable perception of QWL and high OC are consistent with the individual's perception of external prestige attributed to membership of a prestigious organisation.

The primary proposition of Korman's (1977) self-consistency theory is that all other things being equal, individuals will engage in and find satisfying those behaviours that maximise their sense of cognitive balance or consistency. To incorporate PEP into the QWL-OC relationship, PEP is viewed as an esteem-enhancing social identity response to a psychologically meaningful work experience. In most African cultural settings, such as Ghana, people derive prestige in membership of a group perceived to have favourable reputations (Monroe, 1983). Therefore, employment in an organisation that is perceived to have favourable PEP in the eyes of the public can satisfy an individual's latent need for prestige. According to Herrbach et al. (2004), PEP is derivable from three sources. Firstly, PEP can be linked to historical recognition. In an instance where an organisation is historically connected to the social or economic development within its sphere of operation, the organisation becomes a landmark that is linked with the country or region because it overlaps with its history (e.g. Ghana Cocoa Marketing Board). The popularity, prestige and historical recognition the organisation enjoys from the public may rub off on its employees. The second source is the value placed on the product that the organisation manufactures, or the fact that its services are directed towards an up-market clientele. Thirdly, an organisation can be esteemed by its clientele and the general public for its innovative human resource initiatives, profitability, growth rate and the size of its workforce. 
Empirical research has provided support for the moderating effects of PEP. In a study by Smidts et al. (2001), PEP moderated the relationship between employee communication and organisational identification. Carmeli (2005) reports a moderating effect of PEP on the relationship between job satisfaction and organisational citizenship behaviour. Although empirical evidence in direct support of the mediating effect of $\mathrm{PEP}$ on the QWL-OC link is rare in the literature, it is plausible that PEP can play a mediating role in the relationship between QWL and OC. As Vergin and Qoronfleh (1998) and Smidts et al. (2001) have pointed out, PEP is an output of better QWL and research has shown that it is an antecedent of OC. Accordingly, it is possible that since employees' psychological identification with their organisation (PEP) tends to boost their self-esteem, PEP can enhance the relationship between their perception of QWL and OC. To maintain their self-esteem, employees may remain committed to the organisation that is providing this intrinsic need. This study takes into consideration the gap in knowledge by investigating the mediating role of PEP on the direct behavioural exchange relationship between QWL and OC. Therefore, there is a need for new knowledge about the impact of moderating variables on the relationship between QWL and OC. Therefore, it is proposed that the relationship between QWL and OC will be strongest when employees have positive PEP.

Joiner and Bakalis (2006) suggest that some demographic variables can predict a variety of job outcomes, including employee's commitment. Therefore, gender, age, marital status and tenure were included as control variables in this study. Research by Dunham, Grube and Castaneda (1994) found a significant relationship between OC and age. Gerhart (1990) found a positive relationship between OC and tenure. Research evidence on the relationship between gender and OC is inconsistent. Ngo and Tsang (1998) did not find a relationship between gender and OC, whilst Mathieu and Zajac (1990) reported that women are more likely to report higher OC than their male counterparts.

\section{Research design Research approach}

The authors achieved the objectives they set out for this study by using a cross-sectional quantitative survey research design to pursue their study objective. A survey questionnaire was distributed to employees within two large public organisations in Ghana.

\section{Research method}

\section{Participants}

Data was received from 137 respondents, representing a 46\% response rate. Ages of respondents range from 26-55 years (mean $=40 ; \mathrm{SD}=7.6$ ). $53 \%$ were men and $47 \%$ were women. Table 1 presents the demographics of the participants.

\section{Measuring instrument}

A biographical questionnaire was administered in order to document the socio-demographic characteristics of the
TABLE 1: Percentage of responses by category of gender, organisational status and marital status $(n=137)$.

\begin{tabular}{lll}
\hline Characteristics & $f$ & $\%$ \\
\hline Gender & 72 & \\
Male & 65 & 52.6 \\
Female & & 47.4 \\
Organisational position $\dagger$ & 44 & \\
Senior staff & 56 & 32.1 \\
Junior staff & & 67.9 \\
Tenure (years) & 25 & \\
1-5 & 42 & 18.2 \\
5-10 & 36 & 30.7 \\
10-15 & 34 & 26.3 \\
15+ & & 24.8 \\
Marital status & 41 & 29.9 \\
Single & 96 & 70.1 \\
Married &
\end{tabular}

$f$, frequency.

$\uparrow, 37$ participants did not indicate their current organisational positions.

participants. Questions covered gender, age, marital status, tenure and organisational position.

Perceived external prestige was measured using the six-item 'Perceived Organisational Prestige Scale' (Mael \& Ashforth, 1992). It has a response format on a five-point Likert scale ranging from strongly disagree (1) to strongly agree (5). The items included: (1) 'People in my community think highly of my organisation' and (2) 'My organisation does not have a good reputation in my community' (reversed). The minimum score obtainable on the scale is 6 and the maximum is 30 . High scores represent high PEP. This measure has been used by numerous scholars, including Herrbach et al. (2004) ( $\alpha=$ 0.69) and Lipponen, Helkama, Olkkonen and Juslin (2005) $(\alpha=0.83)$. In this study it displayed an internal consistency reliability $(\alpha)$ of 0.79 .

Quality of work life was tapped with a 12-item scale developed by Huang et al. (2007). The scale has four dimensions (work life balance, job characteristics, supervisory behaviour and compensation and benefits). Each QWL dimension was measured by three items. The items included: (1) ‘My current job does not interrupt my family life', (2) 'My job permits me to decide on my own how to go about doing the work', (3) 'My supervisor instructs me how to improve my job' and (4) 'I am fairly rewarded compared to similar jobs in my organisation'. Respondents indicated their perception about each question on a six-point Likert scale ranging from strongly agree (6) to strongly disagree (1). The minimum score obtainable on the scale is 12 and the maximum is 72 . High scores indicate a favourable perception of QWL. Internal consistency of the scale ranges between 0.70 and 0.86 in prior studies (Huang et al., 2007). A Cronbach's alpha of 0.764 was reported in this study.

Organisational commitment was measured using a 15-item 'Organisational Commitment Questionnaire' (Mowday, Steers \& Porter, 1979). Responses were given on a seven-point Likert scale ranging from strongly disagree (1) to strongly agree (7). Example of items are: (1) 'I am willing to put in a great deal of effort beyond that normally expected in order to 
help this organisation to be successful' and (2) 'Deciding to work for this organisation was a definite mistake on my part'. High scores represent high OC. The instrument has been tested with different research samples and appears to yield consistent results across samples (Aryee \& Debrah, 1992). A reliability of 0.823 was reported for the present study.

\section{Procedure}

The sample size was determined based on the suggestion of Fowler (1995) that beyond a sample size of 150-200 there is only a modest gain to increasing the sample size. A general guideline for an appropriate sample size to make the findings useful was determined by the relation $N>50+8 m$, where $m$ is the number of independent variables to be used and $N$ is the sample size in the research (Krosnick, 1999). Because the present study has two independent variables, it requires a minimum sample of 66 participants.

Existing scales were adapted for the study. However, because the study was conducted in the Ghanaian context, which may be different from the environments in which the scales were developed, a pilot study was conducted amongst employees from two public organisations that were not included in the main study to identify questions that respondents may find difficult or could interpret differently than intended. The results of the pilot study show that the content of the questionnaires and instructions were clear. No change was therefore made on the questionnaire to be used for the main study.

The main study was conducted two weeks after the pilot study. Before the commencement of the main study, four public service organisations in the Accra metropolis were approached for approval to conduct the survey. The four organisations were selected due to their large sizes and the fact that they had more than 200 employees in their employment. Specifically, two of these organisations were chosen because they possess distinct characteristics needed to examine the prestige-related variable in the study. However, only two of the four organisations that were selected agreed to participate in the study. One of the organisations has its services directed towards an up-market clientele and operates at the national and international levels, whilst the second renders services only at the national level. As argued by Herrbach et al. (2004), one of the ways in which prestige is derived is when the organisation renders service to a prestigious clientele. Furthermore, the public sector was seen as the appropriate environment in which to study OC, as non-commitment behaviours (e.g. absenteeism) tend to be higher in public sector organisations than in the private sector (Owusu, 2004).

Participants received a survey package through the administrative director's assistants, who introduced the researchers to departmental heads and requested their support for the research. To assure confidentiality and anonymity, a statement on the questionnaire stated that participation was voluntary, that responses will be treated confidentially and would be reported only in aggregate form to protect the identities of respondents. Participants were informed not to write their names or that of their organisation on the questionnaires. Respondents were also assured in writing and verbally that no harm would befall them for participating in the study. A research assistant was assigned to collect the completed questionnaires directly from the various departments after two weeks.

Of the 295 questionnaires administered, only 137 questionnaires were received, representing a $46 \%$ response rate. The low response rate was not surprising because of the reluctance of organisational heads to approve the study and the participants' reaction. The survey was conducted during a tough time in Ghana when most organisations were wary of researchers because of the disclosure of numerous wrong-doings and misconducts in public organisations by the undercover investigator popularly known as 'Anas Amereyaw'. Pencils were added to each questionnaire as a token of appreciation for participating.

\section{Data analysis}

SPSS program version 22 was used for the data entry and analysis. Descriptive statistics (e.g. means, standard deviations, skewness and kurtosis) were examined. To specify the relationship between the variables, the data were subjected to Pearson product-moment correlation analysis. Hierarchical multiple regression analysis was performed in order to determine the mediating role of PEP on the relationship between QWL and OC.

\section{Results}

The use of multivariate design such as regression analysis requires that the data be normally distributed. That is, the data gathered on the variables must follow the normal curve assumption. A data set is said to be normal when the skewness and kurtosis values fall between 2 and -2 (Tabachnick \& Fidell, 2007). In large samples (i.e. over 200 participants), skewness does not make a substantive difference in the analysis (Tabachnik \& Fidell, 2007). In this study, the data gathered did not meet the requirement for normality because the sample size was less than 200; thus, skewness was thought to be a risk for this study. The data gathered was transformed following the procedure of Tabachnick \& Fidell (2007). Because the original data was negatively skewed, the transformation formula for negative values was used: Logarithmic $(\log 10)$ NEWX $=$ LG10(K-X), where NEWX is the transformed variable, $K$ is the maximum score and $\mathrm{X}$ is the original variable. The individual scores on each variable were first multiplied by -1 and the result was added to the maximum score on the variable. The square roots of the obtained results were then calculated and the result represented the transformed scores that were used in the analysis. Histograms for the distribution of each scale were reviewed and all the scales appear to be normally distributed. The maximum and minimum scores, means, 
standard deviations, skewness and kurtosis of the study variables are presented in Table 2.

All the measures indicated smaller standard deviations in relation to the means, which indicates that the majority of the respondents' scores were close to the mean scores; thus, individual variations as compared to the means was not widely spread.

According to Baron and Kenny (1986), to test mediation, relationships amongst the predictor, the outcome variable and the mediator must be significant. That is, before one looks for variables that mediate an effect, there should be an effect to mediate. The correlations of the study variables are presented in Table 3.

The results show that the demographic variables of gender, age, marital status and tenure were not significantly related to OC. As a result, their influence on the dependent variable is curtailed. The correlation coefficients indicate that PEP had a low correlation with OC $(r=0.325 ; p<0.01)$ and a substantial correlation with QWL $(r=0.627 ; p<0.01)$. The correlation between QWL and OC was moderate $(r=$ 0.390; $p<0.01)$. All the correlations amongst the predictor, the mediator and the outcome variables were positive and therefore in the expected direction. In all, the correlations were not high enough to indicate multi-collinearity (Field, 2005). The results indicate a significant relationship between QWL and OC, between PEP and OC and between QWL and PEP; thus, the data satisfies all the conditions for mediation.

\section{Testing the hypothesised model}

To test the mediation hypothesis, hierarchical multiple regression analysis was used. Three regression equations were performed. Baron \& Kenny (1986) suggest that mediation is indicated if the effect of the independent variable on the outcome variable substantially decreases upon the addition of the mediator whilst the mediator has a significant effect on the outcome variable. The result is presented in Table 4 .

In the first equation, $\mathrm{OC}$ was regressed on the quality of work life. QWL was significantly related to OC $(\beta=0.340 ; t=4.205$; $p<0.001)$. In the second equation, perceived external prestige was regressed on the QWL; the result shows that QWL had significant influence on PEP $(\beta=0.689 ; t=11.049 ; p<0.001)$. In the third equation, the mediator (PEP) and the predictor (QWL) were simultaneously entered into the equation, the mediator was found to significantly influence $O C$

TABLE 2: Summary of the means, standard deviation, skewness and kurtosis.

\begin{tabular}{|c|c|c|c|c|c|c|c|c|c|}
\hline Variable & $N$ & Minimum & Maximum & Mean & SD & Skewness & SE & Kurtosis & SE \\
\hline PEP & 137 & 14 & 30 & 23.23 & 3.38 & -0.528 & 0.207 & 1.424 & 0.411 \\
\hline QWL & 137 & 50 & 72 & 68.82 & 4.62 & -1.249 & 0.207 & 1.242 & 0.411 \\
\hline OC & 137 & 34 & 101 & 93.55 & 6.79 & 1.332 & 0.207 & 6.837 & 0.411 \\
\hline
\end{tabular}

SD, standard deviation; SE, standard error; OC, Organisational commitment; PEP, Perceived external prestige; QWL, Quality of work life.

TABLE 3: Correlation among study variables.

\begin{tabular}{|c|c|c|c|c|c|c|c|}
\hline Variables & Gender & Age & Marital status & Tenure & QWL & PEP & $O C$ \\
\hline Gender & - & -0.131 & 0.110 & $-0.160 *$ & 0.020 & -0.053 & -0.034 \\
\hline Age & - & - & $0.608^{* *}$ & $0.773 * *$ & $0.177^{*}$ & $-0.220 * *$ & 0.114 \\
\hline Marital status & - & - & - & $0.510 * *$ & 0.013 & -0.138 & 0.049 \\
\hline Tenure & - & - & - & - & $0.185 *$ & $-0.183^{*}$ & -0.050 \\
\hline QWL & - & - & - & - & - & $0.627^{* *}$ & $0.390 * *$ \\
\hline PEP & - & - & - & - & - & - & $0.325 * *$ \\
\hline OC & - & - & - & - & - & - & - \\
\hline
\end{tabular}

TABLE 4: Hierarchical multiple regressions for perceived external prestige as mediator in the relationship between quality of work life and organisational commitment.

\begin{tabular}{|c|c|c|c|c|c|c|c|c|c|c|}
\hline Variable & B & SE & Beta & $t$ & $p$ & $R$ & $R^{2}$ & $\Delta R^{2}$ & $F(1,135)$ & $\Delta F$ \\
\hline $\begin{array}{l}\text { Model } 1 \\
\text { (Constant) }\end{array}$ & 61.606 & 7.616 & - & 8.090 & 0.000 & - & - & - & - & - \\
\hline Quality of work life & 0.501 & 0.119 & 0.340 & 4.205 & 0.000 & - & - & - & - & - \\
\hline- & - & - & - & - & - & 0.340 & 0.116 & 0.116 & 17.683 & $17.683 * *$ \\
\hline $\begin{array}{l}\text { Model } 2 \\
\text { (Constant) }\end{array}$ & 8.931 & 2.911 & - & 3.060 & 0.003 & - & - & - & - & - \\
\hline Quality of work life & 0.504 & 0.046 & 0.689 & 11.049 & 0.000 & - & - & - & - & - \\
\hline $\begin{array}{l}\text { Model } 3 \\
\text { (Constant) }\end{array}$ & 62.903 & 7.892 & - & 7.970 & 0.000 & - & - & - & - & - \\
\hline Quality of work life & 0.427 & 0.165 & 0.291 & 2.596 & 0.010 & - & - & - & - & - \\
\hline PEP & 0.145 & 0.225 & 0.372 & 3.290 & 0.006 & - & - & - & - & - \\
\hline - & - & - & - & - & - & 0.344 & 0.119 & 0.003 & 9.011 & $9.011 * *$ \\
\hline
\end{tabular}

B, beta; $\mathrm{SE}$, standard error, $t, t$-statistic; $R^{2}, R$-squared; $\Delta R^{2}$, adjusted $R$-squared; $F, F$-value.

B, beta; SE, Stand $p<0.001$
. 
$(\beta=0.372, t=3.290, p<0.006)$. The results also indicate that the relationship between QWL and OC remained significant; with the inclusion of the PEP in the third equation it was reduced from what it was in first equation (0.340-0.291, $p<0.010)$. In addition, the beta value of QWL in the third equation diminished by $0.049(0.340-0.291 ; p<0.010)$, suggesting the inclusion of PEP in this equation reduced the influence of QWL on OC. This indicates that about one-third (0.144) of the influence of the QWL on OC (0.049/0.340) goes through the mediating variable of $\mathrm{PEP}$, and about two-thirds of the influence is direct.

To test whether PEP significantly mediates the QWL-OC relationship, the Sobel test was also performed (Sobel, 1982). The Sobel test indicates whether the indirect effect of the independent variable on the dependent variable through the mediator variable is significant. The Sobel test $(z=1.643$; $p<0.05)$ reveals that PEP mediated the positive effects of QWL on OC. There was thus a significant partial mediation effect of PEP on the relationship between QWL and OC. This means that higher QWL is more likely to induce greater OC; likewise, higher QWL promotes PEP and, in turn, greater OC. Therefore, the hypothesis of the study was supported. Figure 1 illustrates the direct and indirect paths in the models.

\section{Discussion}

The article examines if QWL is related to both PEP and OC, investigates if PEP is related to OC and determines whether PEP mediates the relationship between QWL and OC. The overall findings provide evidence for the partial mediation of PEP in the relationship between QWL and OC for a sample of public employees in Ghana. This result is in accordance with propositions of SET, SIT and self-consistency theory. The results of this study also corroborate with findings which showed that QWL and PEP are significantly related to OC (Ashforth \& Mael, 2002; Bagtasos, 2011; Carmeli, 2005;

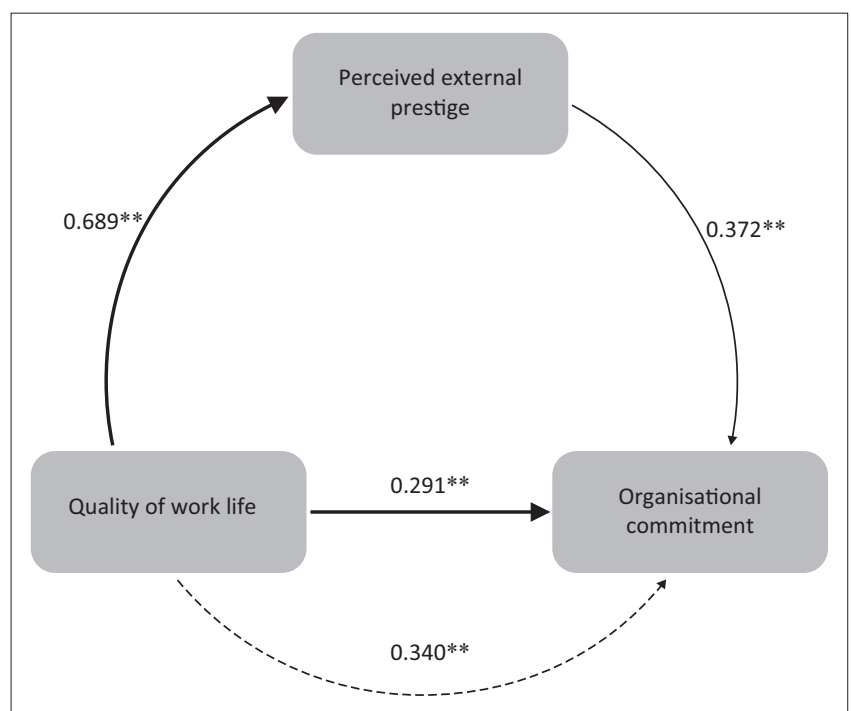

FIGURE 1: Mediating model showing the relationship between quality of work life and organisational commitment, as mediated by perceived external prestige. Along the lower path, the dashed line indicates the indirect effect of quality of work life when perceived external prestige is included in the model. Asterisks indicate significant path coefficients $(* * p<0.001)$.
Saklani, 2010). This study extends existing studies on QWL and $\mathrm{OC}$ of public sector employees by explicitly considering the mediating role of PEP in the QWL-OC link. The findings establish QWL as an indirect antecedent of OC through PEP. The findings provide information that may allow public organisation managers to improve the organisational commitment of their employees.

More specifically, the findings show that QWL significantly predicts PEP and OC. This suggests that increase in quality of work life was positively related to both PEP and OC. The results indicate that institutionalising an organisational culture that promotes good quality of work life and boosting the external prestige of the organisation in the mind of the employees are more likely to enhance OC. This finding is consistent with previous research that found that QWL explains OC (Ma et al., 2011; Normala, 2010). It is possible that employees were being adequately compensated in relation to their work inputs, which enhances their QWL perceptions, which in turn resulted in their willingness to exhibit more OC (Bagtasos, 2011; Saklani, 2010). Social exchange and norm of reciprocity theorists contend that that when employees perceive that their needs are being met, it is more likely that they will honour their side of the relationship by behaving in ways that benefit the organisation. Such equitable perception seems to promote greater level of commitment.

In this study we found that QWL is significantly related to $\mathrm{PEP}$, which means that organisational commitment increases only when employees have a favourable perception of QWL. This finding validates social identification theory (Tajfel, 1978), which suggests that positive self-identity of individuals is, in great part, a product of the group they associate with; hence, the perception of QWL is central to the employees image. In line with Haslam (2004), indicating the importance of employees' perception of their social environment in their self-perception, the favourable perception of QWL may provoke a feeling of positive image in employees. Therefore, public organisation managers should focus on workers' welfare by providing an organisational culture that enshrines participatory problemsolving methods, innovative reward systems and improves work environments, fair supervisory behaviour and work life balance initiatives in order to enhance their self-image in the organisation.

Our findings confirm that PEP is positively linked to OC of employees. This confirms theoretical reasoning (Blau, 1964; Haslam, 2004) and the findings of previous studies (Carmeli, 2005; Dutton et al., 1994; Herrbach et al., 2004; Smidts et al., 2001). The finding indicates that when employees feel their organisation is attractive to outsiders or enjoys favourable external prestige, they are more likely to be more committed. Thus, understanding what constitutes external prestige to employees may be important for building OC.

Lastly, our findings confirm that PEP mediates the relationship between QWL and OC. Specifically, QWL 
predicted OC not only directly but also indirectly, via PEP. Thus, our findings show that PEP can be considered an identity-related construct that may have beneficial effects on employee commitment. More precisely, employees' favourable perception of their QWL may function as a social status enhancement that builds PEP, which, in turn, may affect OC positively, thus supporting self-consistency theory.

\section{Limitations of the study and suggestions for future research}

Like all studies, this one is not without limitations. Asking sensitive questions like those focusing on OC may enhance social desirability bias, especially when employees believe that their employer may see their responses. Therefore, a limitation of this study is the use of self-report measures to assess the constructs. An additional limitation is the sample size and the use of only two public sector organisations; therefore, the results are somewhat limited in generalisability. In spite of these limitations, the findings assists in understanding the role of the concepts studied in employee commitment and adds to the growing body of literature on QWL and OC in Ghana.

\section{Conclusion, recommendations and implications for managers}

This study investigated an identity-related construct (PEP) as a mediator of the QWL-OC link in two public sector organisations in Ghana. A correlational survey was designed to answer the research hypotheses generated from the review of the literature. SET, SIT and self-consistency theory provide the general theoretical framework for this study. This study supported prior research that QWL has a significant effect on OC of employees. Additionally, the findings reveal that QWL could lead to PEP and in turn higher OC (i.e. PEP mediates the relationship between QW and OC). Lastly, PEP explained why there is a relation between QWL and OC, but it did not add to the strength of the relationship. It was recommended that future research in this area should focus on identifying alternative models with the variables studied, investigating other types of organisations with a larger sample size and using structural equation modelling (SEM) to see if similar findings emerge.

\section{Acknowledgements}

This work was conducted in partial fulfilment of the degree of MSc Industrial Psychology at the University of Ghana, Legon (Ghana). To the administrative directors and participants who took the time to complete the research instruments and return them on time, we say thank you.

\section{Competing interests}

The authors declare that they have no financial or personal relationship(s) that may have inappropriately influenced them in writing this article.

\section{Authors' contributions}

O.O. (North-West University, South Africa \& Adekunle Ajasin University) prepared the manuscript, study design, data analysis and interpretation of the results. E.S.I. (NorthWest University) facilitated manuscript preparation. M.D. (University of Ghana) performed the literature search and data collection. All authors have read and approved final manuscript.

\section{References}

Ahsan, N., Fie, D.Y.G., Foong, Y.P., \& Alam, S.S. (2013). Relationship between retention factors and affective organisational commitment among knowledge workers in Malaysia. Journal of Business Economic and Management, 14(5), 903-922. http:// dx.doi.org/10.3846/16111699.2012.701226

Antwi, K.B. (2009). Evidence from Ghana's local government service. Journal of Management Development, 28(6), 504-512. http://dx.doi. org/10.1177/031289629301700201

Aryee, S., \& Debrah, Y. (1992). An investigation of the impact of family and career variables on organisational commitment. Australian Journal of Management 17(2), 175-193.

Ashforth, B.E., \& Mael, F. (2002). Social identity theory and the organization. Academy of Management Review, 14, 20-39. http://dx.doi.org/10.2307/258189

Asiedu, A.B. (2010). Some perspectives on the migration of skilled professionals from Ghana. African Studies Review, 53(1), 61-78. http://dx.doi.org/10.1353/ arw. 0.0324

Bagtasos, M.R. (2011). Quality of work life: A review of literature. DLSU Business \& Economics Review, 20(2), 1-8. http://dx.doi.org/10.3860/ber.v20i2.1909

Baron, R.M., \& Kenny, D.A. (1986). The moderator-mediator variable distinction in social behaviours. Organisation Studies, 26, 443-464.

Bhattacharya, C., \& Elsbach, K. (2002). Us versus them: The roles of organisational identification and dis-identification in social marketing initiatives. Journal of Public Policy \& Marketing, 21(1), 26-36. http://dx.doi.org/10.1509/jppm.21.1.26.17608

Blau, P.M. (1964). Exchange and power in social life. New York, NY: Wiley.

Carmeli, A. (2005). Perceived external prestige, affective commitment, and citizenship behaviours. Organisation Studies, 26, 443-464. http://dx.doi. org/10.1177/0170840605050875

Damayanty, N. (2009). The relationship between retention factors and caree commitment. Retrieved May 17, 2011, from http://scholar.googleusercontent. com/scholar?q=cache:SI04qA058dYJ:scholar.google.com/\&hl=en\&as_ $\mathrm{sdt}=0,5 \&$ as vis $=1$

Dunham, B., Grube, A., \& Castaneda, B. (1994). Organisational commitment: The utility of an integrative definition. Journal of Applied Psychology, 79(3), 370-380. http://dx.doi.org/10.1037/0021-9010.79.3.370

Dutton, J.E., Dukerich, J.M., \& Harquail, C.V. (1994). Organisational images and member identification. Administrative Science Quarterly, 39, 239-263.

Efraty, D., \& Sirgy, J.M. (2004). The effects of QWL on employee behavioural responses. Springer, 22, 31-47.

Farh, J.L., Podsakoff, P.M., \& Organ, D.W. (1990). Accounting for organisational citizenship behaviour: Leader fairness and task scope versus satisfaction. Journal of Management, 16, 705-721. http://dx.doi.org/10.1177/014920639001600404

Field, A. (2005). Discovering statistics using SPSS. London, UK: Sage Publications.

Fowler, F.J. (1995). Survey research methods. Newbury Park, CA: Sage.

Fuller, J.B., Hester, K., Barnett, T., Frey, L., \& Relyea, C. (2006). Perceived organisational support and perceived external prestige: Predicting organizational attachment for university faculty, staff and administrators. Journal of Social Psychology, 146, 327-347. http://dx.doi.org/10.3200/SOCP.146.3.327-347

Geldenhuys, M., Łaba, K., \& Venter, C.M. (2014). Meaningful work, work engagement and organisational commitment. SA Journal of Industrial Psychology/SA Tydskrif vir Bedryfsielkunde, 40(1), Art. \#1098, 10 pages. http://dx.doi.org/10.4102/sajip. v40i1.1098

Gerhart, B. (1990). Voluntary turnover and alternative job opportunities. Journal of Applied Psychology, 75, 467-476. http://dx.doi.org/10.1037/0021-9010.75.5.467

Goldberg, L.R. (1990). An alternative description of personality: The Big-Five factor structure. Journal of Personality and Social Psychology, 59, 2116-1229. http:// dx.doi.org/10.1037//0022-3514.59.6.1216

Gouldner, A.W. (1960). The norm of reciprocity: A preliminary statement. American Psychological Review, 25(2), 161-178. http://dx.doi.org/10.2307/2092623

Guerrero, S., \& Herrbach, O. (2009). Manager organisational commitment: A question of support or image? The International Journal of Human Resource Management 20(7), 1536-1553. http://dx.doi.org/10.1080/09585190902983496

Haslam, S.A. (2004). Psychology in organisations: The social identity approach. (2nd edn.). Thousand Oaks, CA: Sage Publications.

Hausmann, N., Mueller, K., Hattrup, K., \& Spiess, S.O. (2013). An investigation of the relationships between affective organisational commitment and national differences in positivity and life satisfaction. Applied Psychology: An International Review, 62(2), 260-285. http://dx.doi.org/10.1111/j.1464-0597.2012.00500.x 
Havlovic, S.J. (1991). Quality of work life and human resource outcomes. Industria Relations, 30(3), 469-479. http://dx.doi.org/10.1111/j.1468-232X.1991.tb00799.x

Herrbach, O., Mignonac, K., \& Gatignon, A.L. (2004). Exploring the role of perceived external prestige in managers' turnover intentions. Internationa Journal of Human Resource Management, 15(8), 1390-1407. http://dx.doi. org/10.1080/0958519042000257995

Homans, G.C. (1961). Social behaviour: Its elementary forms. New York, NY: Harcourt, Brace, \& World

Huang, T.C., Lawler, J., \& Lei, C.Y. (2007). The effects of quality of work life on commitment and turnover intention. Social Behaviour and Personality, 35(6), 735-750. http://dx.doi.org/10.2224/sbp.2007.35.6.735

Joiner, T.A., \& Bakalis, S. (2006). The antecedents of organisational commitment: The case of Australian casual academics. The International Journal of Educational Management, 20(6), 439. http://dx.doi.org/10.1108/09513540610683694

Koonmee, K., Singhapakdi, A., Virakul, B., \& Lee, D.J. (2011). Ethics institutionalisation, quality of work life and employees job related outcomes: A survey of human resource managers in Thailand. Journal of Business Research, 63, 20-26. http:// dx.doi.org/10.1016/j.jbusres.2009.01.006

Korman, A.K. (1977). Organisational behaviour. Englewood Cliffs, NJ: Prentice-Hall. http://dx.doi.org/10.1016/0030-5073(77)90022-8

Krosnick, J. (1999). Survey research. Annual Review of Psychology, 50, 537-556. http://dx.doi.org/10.1146/annurev.psych.50.1.537

Lee, D., Singhapakdi, A., \& Sirgy, J. (2007). Further validation of a need-based qualityof- work-life (QWL) measure: Evidence from marketing practitioners. Applied Research in Quality of Life, 2(4), 273-287. http://dx.doi.org/10.1007/s11482-0089042-x

Lipponen, J., Helkama, K., Olkkonen, E., \& Juslin, M. (2005). Predicting the different profiles of organisational identification: A case of shipyard subcontractors. Journal of Occupational and Organisational Psychology, 78, 97-112. http://dx.doi. org $/ 10.1348 / 096317904 \times 22935$

Ma, Y., Ma, Q., Yu, H., \& Hao, J. (2011). Quality of work life and employee outcomes: A survey of employees in hotel business. Advanced Materials Research, 171-172, 433-436.

Mael, F., \& Ashforth, B.E. (1992). Alumni and their alma mater: A partial test of the reformulated of organisational identification. Management Review, 14(1), 20-39. http://dx.doi.org/10.1002/job.4030130202

Mathieu, J.E., \& Zajac, D. (1990). A review and meta-analysis of the antecedents, correlates, and consequences of organisational commitment. Psychological Bulletin, 108(2), 171-194. http://dx.doi.org/10.1037/0033-2909.108.2.171

May, B.E., Lau, R.S.M., \& Johnson, S.K. (1999). A longitudinal study of quality of work life and business performance. South Dakota Business Review, 58(2), 3-7.

Meyer, J.P., \& Allen, N.J. (1997). Commitment in the workplace: Theory, research and application. London, UK: Sage.

Monroe, D. (1983). Developing La Conscience Professionelle in cultures of vocational disadvantage. In F. Blacker (Ed.), Social psychology and developing countries (pp. 51-69). London, UK: Wiley.

Moss, S.A., McFarland, J., Ngu, S., \& Kijowska, A. (2007). Maintaining an open mind to closed individuals: The effect of resource availability and leadership style on the association between openness to experience and organisational commitment. Journal of Research in Personality, 41(2), 259-275. http://dx.doi.org/10.1016/j. jrp.2006.03.009

Mowday, R.T., Porter, L.M., \& Steers, R.M. (1982). Employee-organisational linkage New York, NY: Academic Press. http://dx.doi.org/10.1016/B978-0-12-5093705.50011-3

Mowday, R., Steers, R., \& Porter, L. (1979). The measurement of organisational commitment. Journal of Vocational Behaviour, 14, 224-247. http://dx.doi. org/10.1016/0001-8791(79)90072-1

Munene, J.C. (1995). Not-on-seat: An investigation of some correlates of organisational citizenship behaviour in Nigeria. Applied Psychology: An International Review, 44(2), 111-122. http://dx.doi.org/10.1111/j.1464-0597.1995.tb01069.x
Ngo, H.Y., \& Tsang, A.W.N. (1998). Employment practices and organisational commitment: Differential effects for men and women? The International Journal commitment: Differential effects for men and women? The International Journd
of Organisational Analysis, 6, 251-266. http://dx.doi.org/10.1108/eb028887

Normala, D. (2010). Investigating the relationship between quality of work life and organisational commitment amongst employees in Malaysia. International Journal of Business \& Management, 5(10), 75-82.

Owusu, F. (2004). Organisational culture and the performance of public organisations in Ghana: Learning from good performers. Report submitted to PREM public sector department, governance knowledge sharing programme. Washington, DC: The World Bank.

Raja, P.J.A., \& Kumar, S.A. (2013). A study on quality of work life of employees in steel authority of India, Salem. Retrieved March 24, 2014, from http://www.academia. edu/5742713/IJEMR_3(6)_online

Rathi, N. (2010). Relationship of quality of work life with employee's psychological well-being. International Journal of Business Insights and Transformation, 3(1) $52-60$.

Rhoades, L., \& Eisenberger, R. (2002). Perceived organisational support: A review of the literature. Journal of Applied Psychology, 87(4), 698-714. http://dx.doi. org/10.1037/0021-9010.87.4.698

Saklani, D.R. (2010). Non-managerial perspective of quality of work life. Journal of Management Research, 10(20), 87-102.

Simintiras, A., Watkins, A., Ifie, K., \& Georgakas, K. (2012). Individual and contextual influences on the affective commitment of retail salespeople. Journal of Marketing Management, 28(11-12), 1377-1398. http://dx.doi.org/10.1080/026 7257X.2012.691529

Smidts, A., Pruyn, A.T.H., \& Van Riel, C.B.M. (2001). The impact of employee communication and perceived external prestige on organisational identification. Academy of Management Journal, 44, 1051-1062. http://dx.doi. org/10.2307/3069448

Sobel, M.E. (1982). Asymptotic confidence intervals for indirect effects in structural equation models. Sociological Methodology, 13, 290-312. http://dx.doi. org $/ 10.2307 / 270723$

SPSS 22.0 for Windows [Computer software]. (2014). Chicago, IL: SPSS Inc.

Sung, M., \& Yang, S.U. (2008). Toward the model of university image: The influence of brand personality, external prestige, and reputation. Journal of Public Relations Research, 20(4), 357-376. http://dx.doi.org/10.1080/10627260802153207

Tabachnick, B.G., \& Fidell, L.S. (2007). Using multivariate statistics. (5th edn.). Boston, MA: Allyn and Bacon.

Tajfel, M. (1978). Differentiation between social groups. London, UK: Academic Press.

Tankebe, J. (2010). Identifying the correlates of police organisational commitment in Ghana.Police Quarterly, 13,73-91.http://dx.doi.org/10.1177/1098611109357324

Thibaut, J.W., \& Kelley, H.H. (1959). Social psychology of groups. New York, NY: Wiley.

Triandis, H.C. (1984). Towards a psychological theory of economic growth. Internationa Journal of Psychology, 19, 79-95. http://dx.doi.org/10.1080/00207598408247517

Tyler, T.R., \& Blader, S.L. (2003). The group engagement model: Procedural justice, social identity, and cooperative behaviour. Personality and Social Psychology Review, 7, 349-361. http://dx.doi.org/10.1207/S15327957PSPR0704_07

Vagharseyyedin, S.A., Vanaki, Z., \& Mohammadi, E. (2011). The nature of nursing quality of work life: An integrative review of literature. Western Journal of Nursing Research, 33(6), 786-804. http://dx.doi.org/10.1177/0193945910378855

Vergin, R.C., \& Qoronfleh, M.W. (1998). Corporate reputation and the stock market. Business Horizons, 41(1), 19-26. http://dx.doi.org/10.1016/S00076813(98)90060-X

Williamsa, H.M, Raynerb, J., \& Allinson, C.W. (2012). New public management and organisational commitment in the public sector: Testing a mediation model. The International Journal of Human Resource Management, 23(13), 2615-2629. $\mathrm{http}: / /$ dx.doi.org/10.1080/09585192.2011.633275

Young, B.S., Worchel, S., \& Woehr, D. (1998). Organisational commitment among public service employees. Public Personnel Management, 27(3), 339-349. 